Apidologie, 1985, 16 (2), 109-118

\title{
A PRELIMINARY STUDY ON WINTER SURVIVAL OF AFRICANIZED AND EUROPEAN HONEY BEES IN CORDOBA, ARGENTINA
}

\author{
R. KRELL, A. DIETZ and F.A. EISCHEN \\ Department of Entomology (1), University of Georgia, \\ Athens, GA 30602 USA
}

\begin{abstract}
SUMMARY
An overwintering study of different sized honey bee colonies was conducted in the mountain valley of Cura Brochero $(1400 \mathrm{~m})$, Cordoba, Argentina. Food consumption and survival were measured. The test included two colony sizes, 38 of which were populated with 1-2 lbs. of bees per colony, and 40 with 4-6 lbs. of bees per colony. The study site was chosen for its special climatic conditions along the suggested southern distribution limit of Africanized honey bees in Argentina. High daily maximum temperatures allowed bees to fly on all but seven out of 86 days. Extensive perjods of low temperatures were only evident at night. The average daily temperatures for June to September ranged from $8.9^{\circ} \mathrm{C}$ to $12.1^{\circ} \mathrm{C}$. Under the prevailing conditions, no differences in survival or food consumption were found between Africanized and European bees. If other factors such as food and water supplies, nesting sites availability, intensive agriculture, and pesticide application, etc. are not found to limit their distribution, Africanized honey bees should be able to survive further south in Argentina than previously suggested.
\end{abstract}

\section{INTRODUCTION}

The aggressive nature of Africanized honey bees has been covered extensively by the media for many years. Scientific publications on the biology of this insect have received considerably less attention. Methods for quantifying the defensive behavior of Africanized bees have been worked out by STORT (1974) and recently by Collins and KubaseK (1982) and Collins et al. (1982). Despite recent progress in research on the behavioral aspects of this bee, much basic information is still needed on the behavior and biology of the Africanized

(1) This research was supported in part by Cooperative Agreement No. 25-21-RC293-085 (Principal Investigator : Alfred Dierz) from the Bee Breeding and Stock Center Laboratory, U.S.D.A., Baton Rouge, LA. 
honey bee. Estimates on their potential distribution and impact in temperate climates remain hypothetical (TAYLOR, 1977 ; KERR et al., 1982; TAYLOR and SPIVAK, 1984). Fletcher (1978) and WoYKe (1973) reported that $A$.m. adansonii colonies survived during short periods of subzero weather in Africa, and at $0^{\circ}-4{ }^{\circ} \mathrm{C}$ for up to 3 months in Poland, respectively. Some of the objectives of our research currently in progress in Argentina are to determine the factors influencing the behavior and distribution of the Africanized bee. As part of this research effort, an overwintering study was conducted in a mountain valley in Cordoba, Argentina, to compare the effects of cold temperatures on the food consumption and survival of Africanized and European honey bee colonies.

\section{METHODS AND MATERIALS}

The overwintering experiment was started on June 17, 1983, in Cura Brochero (approx. $31^{\circ} 42$ 'S) in a river valley at $1400 \mathrm{~m}$ above sea level on the western side of a dry moutain range, which separates Cura Brochero by roughly $90 \mathrm{~km}$ from the city of Cordoba.

The experimental design included 20 full-sized colonies (4-6 lbs. of bees) and 20 nuclei (1-2 lbs. of bees) of each Africanized and European bees. Full-sized colonies were hived in one Langstroth brood chamber and one shallow super with honey. Nuclei consisted of a standard Langstroth 10 frame brood chamber, but containing only 8 frames. The full-sized European control colonies vatied slighlty in the number of supers per colony.

Africanized colonies were selected from apiaries which were situated in areas assumed to have been colonized by Africanized bees and from beekeepers in those areas who had not requeened their colonies for several years. Individual colonies were chosen on the basis of their defensive behavior as determined by the field test of Collins and Kubasek (1982). Morphometric analysis of the bees from these colonies were not available at the start of the experiment, but we:c subsequently obtained from the U.S.D.A. Bee Breeding and Stock Center Laboratory, Baton Rouge, LA. Distinction between Africanized and European honey bee colonies for this analysis is based solely on the morphometric identifications.

Full-sized colonies of Africanized and European honey bees were moved to the study site on June 17, 1983, from near Parana, Entre Rios. The colonies originated from the area around the city of Santa Fe, S.F., where they had been established from swarms or had been allowed to requeen themselves. Africanized and European honey bee nuclei (VDNA \& VDNE, respectively) were made up with queens and bees of colonies located near Villa Dolores, Cordoba, and were moved to the study site one week prior to the start of the experiment.

Full-sized European colonies were provided by the Cordoba Ministry of Agriculture Experiment Station and headed by naturally mated $F_{1}$ and $F_{2}$ queens raised from U.S. imported queens in nearby Villa de Soto. The European honey bee nuclei intended to be used as controls were made up in Villa de Soto with local non-Africanized bees and queens imported from Claxton, Georgia, USA. All colonies were provisioned with, or had sufficient quantities of honey at the beginning of the experiment. Only the Villa de Soto nuclei were fed during the experiment when needed. All the nuclei were checked once a month for food and general status, and all colonies were weighed at the start of the experiment on June 17, on September 5 and 6 and again on October 4 and 5 .

The temperature data were collected daily at noon with a maximum-minimum thermometer beginning with June 21 until the end of October, except for the last 20 days of July. The average monthly temperature was calculated from the daily maximum and minimum temperatures. It is, therefore, generally slightly higher than the mean calculated from three different day time temperatures by the Argentinian meteorological stations (Fuerza Aerea Argentina, 1961-1970). 


\section{RESULTS}

The final identification of the test colonies can be seen in Table 1. Only five of the 20 full-sized aggressive colonies from Parana (P) were later identified as Africanized honey bees. One colony was not identified. Five of the 20 full-sized control colonies from Cura Brochero (CB) were subsequently also identified as being Africanized and two remained unidentified. Only 6 of the 12 identified nuclei out of 19 from Villa Dolores (VD) were Africanized. Additionally, two colonies from Cura Brochero (one Africanized and one European) were treated as nuclei.

TABL. 1. - Identification of colonies of various origins

\begin{tabular}{c|l|c|c|c}
\hline Origin & \multicolumn{1}{|c|}{ Treatment } & European & Africanized & Unidentified \\
\cline { 1 - 3 } CB & Full-sized colonies & 13 & 5 & 2 \\
P & Full-sized colonies & 14 & 5 & 1 \\
VD & Nuclei colonies & 7 & 7 & 7 \\
VS & Nuclei colonies & 14 & 0 & 3 \\
& Total & 48 & 17 & 13 \\
\hline
\end{tabular}

(CB - Cura Brochero, P - Parana, VD - Villa Dolores, VS - Villa de Soto).

Therefore, a total of 10 Africanized and 27 European full-sized colonies were compared as well as seven European with seven Africanized nuclei (Table 1). Due to the very high loss of control nuclei from Villa de Soto (7 out of 17) by absconding, robbing and starvation within the first month after queen introduction, as well as feeding during the experiment, and their additional exposure to stresses not endured by the other colonies, it was decided not to include these nuclei in the statistical evaluation.

All full-sized colonies survived in excellent condition except for one European colony from Cura Brochero. Of the 21 queenright nuclei from Villa Dolores on June 17, one Africanized and one European nucleus absconded with food present. One Africanized nucleus starved, or was robbed out, and one very weak European nucleus was united with another one. For analyses purpose, the first nucleus was considered dead when united and the latter died after the beginning of the flowering period. All other colonies survived until floral nectar sources became available, except for two unidentified nuclei which died due to robbing, or absconding, between September 13 and October 5. There are no statistical differences in survival between Africanized and European colonies, or nuclei, from either Cura Brochero, Parana or Villa Dolores. 
TABL. 2. - Average weight loss (kg) of full-sized colonies from Cura Brochero, Cordoba (CB), Parana, Entre Rios (P) and nuclei colonies from Villa Dolores, Cordoba (VD) in Cura Brochero between June 17 and Sept. 5 and 6, 1983

\begin{tabular}{c|l|c|c}
\hline \hline \multirow{2}{*}{ Origin } & Treatment & $\begin{array}{c}\text { European } \\
(\mathrm{kg})\end{array}$ & $\begin{array}{c}\text { Africanized } \\
(\mathrm{kg})\end{array}$ \\
\cline { 2 - 4 } $\mathrm{CB}$ & Full-sized colonies & $\overline{\mathrm{X}}=8.53 \mathrm{a}$ & $\overline{\mathrm{X}}=10.88 \mathrm{ab}$ \\
& & $\mathrm{SD}=2.35$ & $\mathrm{SD}=1.97$ \\
$\mathrm{P}$ & Full-sized colonies & $\overline{\mathrm{X}}=14.01 \mathrm{~b}$ & $\overline{\mathrm{X}}=13.68 \mathrm{~b}$ \\
& & $\mathrm{SD}=4.68$ & $\mathrm{SD}=3.70$ \\
$\mathrm{VD}$ & Nuclei colonies & $\overline{\mathrm{X}}=8.64 \mathrm{a}$ & $\overline{\mathrm{X}}=7.78 \mathrm{a}$ \\
& & $\mathrm{SD}=2.36$ & $\mathrm{SD}=1.28$ \\
\hline
\end{tabular}

Means followed by the same letter are note different at $\mathrm{P}<0.05$ (t-test).

A comparison of food consumption in Africanized and European colonies is summarized in Table 2. Bees from Parana, both Africanized and European colonies, consumed more food than the European bees from Cura Brochero ( $\mathbf{P}<0.01$ and $\mathbf{P}<0.005$, respectively). There was no statistical difference in food consumption between the other colonies $(P<0.05)$. The slightly lower consumption by bees in the nuclei was different from that of the Parana colonies $(P<0.05)$. Within each group of Parana, Cura Brochero and Villa Dolores bees there was no difference in food consumption between Africanized and European colonies, neither was there any when the results of both groups of bees of full-sized colonies were lumped together. There was also no statistical difference in weight gain of colonies between September 5 and October 5 (Table 3). It is interesting to note that food consumption of bees did not differ between the large sized, local colonies $(\mathrm{CB})$ and the nuclei $(\mathrm{P}<0.05)$. Only the Parana colonies $(\mathrm{P})$ consumed significantly more honey than the nuclei $(\mathrm{P}<0.05)$.

TABL. 3. - Average weight gains of colonies from Cura Brochero (CB), Parana (P), and Villa Dolores (VD), between Sept. 5 and Oct. 5, 1983

\begin{tabular}{c|c|c|c}
\hline \hline Origin & Treatment & $\begin{array}{c}\text { European } \\
(\mathrm{kg})\end{array}$ & $\begin{array}{c}\text { Africanized } \\
(\mathrm{kg})\end{array}$ \\
\cline { 2 - 3 } $\mathrm{CB}$ & Full-sized colonies & $\overline{\mathrm{X}}=2.80 \mathrm{ab}$ & $\overline{\mathrm{X}}=2.26 \mathrm{ab}$ \\
& & $\mathrm{SD}=2.26$ & $\mathrm{SD}=1.44$ \\
$\mathrm{P}$ & Full-sized colonies & $\overline{\mathrm{X}}=3.575 \mathrm{a}$ & $\overline{\mathrm{X}}=4.275 \mathrm{a}$ \\
& & $\mathrm{SD}=1.46$ & $\mathrm{SD}=1.49$ \\
$\mathrm{VD}$ & Nuclei colonies & $\overline{\mathrm{X}}=1.58 \mathrm{~b}$ & $\overline{\mathrm{X}}=1.88 \mathrm{~b}$ \\
& & $\mathrm{SD}=0.71$ & $\mathrm{SD}=0.71$ \\
\hline
\end{tabular}

Means followed by the same letter are not different at $\mathbf{P}<0.05$ (t-test). 
TABL, 4. - Temperature data collected in Cura Brochero from June 21, 1983, until October 21, 1983

\begin{tabular}{|c|c|c|c|c|c|}
\hline${ }^{\circ} \mathrm{C}$ & June $21-30$ & July $1-11$ & Aug. $1-31^{* * *}$ & Sept. $1-30$ & Oct. $1-20$ \\
\hline Temps. $1200(\overline{\mathbf{x}})$ & $14.00 *$ & 15.55 & 14.68 & 14.27 & \\
\hline Max. Temp. $(\overline{\mathbf{x}})$ & 17.56 & 18.73 & 19.12 & 18.14 & 30.9 \\
\hline 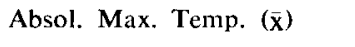 & 23 & 24 & 31 & 25 & 39 \\
\hline Min. Temp. $(\overline{\mathrm{x}})$ & $-1,50$ & 2.18 & 5.12 & 2.77 & 19.6 \\
\hline Absol. Min. Temp. ( $\overrightarrow{\mathrm{x}})$ & -4 & -6 & -3 & -6 & 8 \\
\hline Average & 8.89 & 10.45 & 12.12 & 10.43 & 26.55 \\
\hline
\end{tabular}

* For 26, 28-30 June only.

*: No data for August 21, 23, 26-29.

1 n Min. Temp. ${ }_{n}+$ Max. Temp. $_{n}$

Calculated as follows : $\frac{-}{\mathrm{n}} \sum_{1}-\frac{1}{2}$ ( $\mathrm{n}=\#$ of days).

Temperatures were recorded in the shade at the bee yard. The average daily temperature ranged from $8.9^{\circ} \mathrm{C}$ in June to $10.5^{\circ} \mathrm{C}$ in July, $12.1{ }^{\circ} \mathrm{C}$ in August. $10.4^{\circ} \mathrm{C}$ in September, and $26.6^{\circ} \mathrm{C}$ in October (Table 4). Flight activity was also recorded at noon. Between June 21, 1983, and August 11, 1983, except for July 12-31, flight activity was observed on 25 out of 32 days. During the cooler part of September (September 12-30, 1983), bees were observed flying on 17 out of 18 days.

\section{DISCUSSION}

Since there were no differences in survival between the two different types of bees at the test site, the local climatic winter conditions are apparently not limiting or favoring the survival of either. The survival of Africanized honey bees in the area is also illustrated by the fact that five of the Cura Brochero colonies were Africanized and had (apparently) wintered successfully in prior years.

With the average temperatures of the last days of June as low as $8.9^{\circ} \mathrm{C}$, but bees not being confined for extended periods of time due to high daily temperatures, the bees did not need to stay in a tight cluster continuously. Also, access to all frames of food within the hive as well as daily flights were possible.

As a possible adaptation to the climate, brood rearing had ceased in most colonies from Cura Brochero earlier in May, but was still evident in colonies 
moved to that test site from the warmer area of Parana. Commencement of brood rearing was not recorded. But obviously, the interruption of the brood cycle was not long enough in either case for the reduced longevity of the Africanized honey bees (WOYKE, 1973) to affect the colonies differently.

DARCHEN's (1973) finding of « less perfect» regulation of brood nest temperature by the Apis mellifera adansonii in warm weather in Africa is either not transferable to the Africanized honey bee in cooler weather in South America or, if it is, it neither affects winter survival nor food consumption any differently from that of the European honey bee. Increased energy consumption due to the higher metabolic rate of Africanized bees (HEINRICH, 1979) is either not reflected in our results or it does not contribute significantly to our findings.

Some variations in population size within each group, and the small sample size, probably obscure significant differences in food consumption of the different sized colonies. The Parana (P) colonies had in general slightly larger populations than the colonies from Cura Brochero (CB), but the nuclei had much smaller population sizes than either of the other two. At the $5 \%$ confidence level, some differences between colonies of different sizes and geographic origin become apparent. The confounding factors may be numerous, for example, robbing, continued brood rearing in Parana colonies which had not been exposed prior to the test to cold weather, different heat loss in large versus small winter clusters, etc. But the differences between Africanized and European colonies within each group are insignificant.

Due to the altitude of the test site, climatic conditions are not typical for this latitude. Similar climatic conditions prevail further south in Argentina (Table 4 and Fuerza Aerea Argentina, 1961-1970). It was previously assumed that the study site was near the survival limit for Africanized honey bees. However, our results clearly show that both locally adapted (CB, VD) and what we consider less adapted European and Africanized honey bee colonies from a warmer area (P), overwintered well under the given climatic conditions.

If any of the conditions in Cura Brochero had been close to those that limit Africanized honey bee survival, then at least some mortality or reduction in the full size colonies, and/or a higher mortality in the nuclei due to starvation and the natural decline of populations, would have been expected. The absconding during nectar dearth and cold weather, with food left behind, most likely is detrimental to colony survival. But with it occurring similarly in Africanized and European nuclei, it is not a distinctive adaptation of either unless some of the absconding colonies successfully invade another hive. Therefore, if these climatic factors are of importance, the distribution of Africanized honey bees should be expected further south and west then previously postulated. Supporting evidence for this assumption was reported by DiETz et al. (1985). 
The excellent winter survival of all colonies during this study period does not allow definitive conclusions at this time on the climatic factors or temperatures that are limiting the survival of Africanized honey bees in Argentina. Additional experiments currently in progress under more extreme temperature conditions may elucidate the limiting factors.

Under the described conditions prevailing at Cura Brochero between June 17 and October 5, 1983, there were no differences in survival, food consumption or subsequent weight gain between Africanized and European honey bee colonies of either large or small sizes. However, much colder climatic conditions may be necessary to limit the survival of the Africanized honey bee. Thus, if other factors such as food, water supply, and nesting sites, intensive agriculture and pesticide application, etc. are not found to limit its distribution, we suspect that Africanized honey bees should be able to survive further south in Argentina than was previously assumed.

Received for publication in December 1984.

Accepted for publication in April 1985.

\section{ACKNOWLEDGEMENTS}

We want to express our appreciation for the help of Dr. A. Rambaue and Sr. M.D. Barrionulvo of the Secretaria de Agricultura, Ganaderia y Recoursos Naturales, Cordoba, in providing us with European control colonies, for moving the bees from and to Parana, and for letting us use their facilities in Cura Brochero. We are also grateful to Pedro Vites and Jorge A. Farion for permitting us to use their colonies. Our special thanks go to Sr. Juan RoDRIGUEZ who assisted in making up the nuclei and in weighing and monitoring all colonies during the experiment. We also wish to thank Dr. Thomas E. Rinderer and his staff at the Bee Breeding and Stock Center Laboratory, USDA, Baton Rouge, for the morphometric analyses of the honey bee samples.

\section{RÉSUMÉ}

\section{ETUDE PRELIMINAIRE SUR LA SURVIE HIVERNALE DES ABEILLES AFRICANISEES ET DES ABEILLES EUROPEENNES A CORDOBA, ARGENTINE}

On a comparé l'action des températures basses sur la survie des colonies d'abeilles africanisées et d'abeilles européennes au cours d'une étude menée à Cura Brochero (environ 31.42'S, altitude $1400 \mathrm{~m}$ ), près de Cordoba (Argentine). L'analyse morphométrique des échantillons prélevés a servi à identifier les colonies.

Du 17 juin au 5 octobre 1983, on a testé provenant de 3 lieux différents 27 colonies européennes et 10 africanisées comportant chacune 2 à $3 \mathrm{~kg}$ d'abeilles, ainsi que 7 nuclei européens et 7 africanisés comportant chacun 0,5 à $1 \mathrm{~kg}$ d'abeilles (tabl. 1). Les températures ont varié de $-6^{\circ} \mathrm{C}$ à $31^{\circ} \mathrm{C}$ avec une moyenne de $8,89^{\circ} \mathrm{C}$ en juin et $12,12^{\circ} \mathrm{C}$ en août (Tabl. 4). L'activité de vol a été observéc 42 jours sur 50 . Une seule colonie européenne et 4 nuclei ( 2 africanisés et 2 européens) sont morts et ont déserté avant la première miellée début septembre. Il n'y a pas de différence statistique 
dans la survic entre colonies ou nuclei africanisés et européens. La comparaison de la consommation alimentaire pendant la même période et du gain de poids subséquent n'a pas montré non plus de différence statistique entre colonies ou nuclei africanisés et européens (Tabl. 2 et 3).

Puisqu'il n'y a pas de différence dans la survie entre les deux types d'abeilles sur le lieu d'expérimentation, les conditions climatiques hivernales locales ne doivent pas limiter ni favoriser la survie de l'un ni de l'autre. En raison de l'altitude du lieu d'expérimentation, les conditions climatiques ne sont pas typiques de la latitude considérée, mais sont plus proches de celles qui règnent dans la zone méridionale supposée limite pour la survie des abeilles africanisées $\left(32^{\circ}\right.$ à $34^{\circ} \mathrm{S}$ ). Néanmoins, si l'une quelconque des conditions présentes à Cura Brochero avait été proche de ceiles qui limitent la survie des abeilles africanisées, on aurait au moins pu s'attendre à quelque mortalité ou réduction des colonies et/ou une mortalité plus élevée chez les nuclei due à la famine et au déclin naturel des populations. Des conditions climatiques beaucoup plus froides sont donc nécessaires pour limiter la survie des abeilles africanisées.

Si l'on ne trouve pas d'autres facteurs, tels que nourriture, approvisionnement en eau, sites de nidification, agriculture intensive et traitements pesticides, pour limiter sa répartition, nous estimons les abeilles africanisées capables de survivre en Argentine plus loin vers le sud qu'on ne l'avait précédemment supposé.

\title{
ZUSAMMENFASSUNG
}

\author{
VORLAUFIGE ERGEBNISSE EINER STUDIE \\ ÜBER DIE UBBERWINTERUNG AFRIKANISIERTER \\ UND EUROPAISCHER HONIGBIENEN IN CORDOBA, ARGENTINIEN
}

In Cura Brochero (ungefähr 31"42'S, $1400 \mathrm{~m}$ Höhe) in Cordoba, Argentinien, wurde ein Überwinterungsversuch durchgeführt, um die Auswirkung niedriger Temperaturen auf das Überleben Afrikanisierter und europäischer Bienenvölker zu vergleichen. Die Herkunftsbestimmung der Völker erfolgte durch morphometrische Analyse von Bienenproben.

In der Periode zwischen 17. Juni und 5. Oktober 1983 wurden insgesamt 27 europäische und 10 Afrikanisierte Vollvölker mit 4-6 Pfund $(=1,8-2,7 \mathrm{~kg})$ Bienen, und 7 europäische und 7 Afrikanisierte Völker in Ablegerstärke (0,5-1,0 kg Bienen), die aus drei verschiedenen Orten stammten, getestet (Tab. 1). Die Temperaturen schwankten in dieser Zeit zwischen $-6^{\circ} \mathrm{C}$ und $31^{\circ} \mathrm{C}$ mit Mittelwerten von $8,89^{\circ} \mathrm{C}$ im Juni bis $12,12^{\circ} \mathrm{C}$ im August (Tab. 4). An 42 von 50 Tagen konnte Flugaktivität beobachtet werden. Ein europäisches Vollvolk sowie je zwei Afrikanisierte und europäische Ableger gingen ein, bzw. zogen vor Trachtbeginn Anfang September aus. Es bestand kein statistischer Unterschied im überleben zwischen Afrikanisierten und europäischen Völkern oder Ablegern. Ebensowenig ergaben der Futterverbrauch und die anschließenden Gewichtszunahmen irgendwelche statistischen Unterschiede zwischen den Völkern oder Ablegern der beiden Gruppen (Tab. 2, 3).

Da zwischen diesen beiden Bienenherkünften am Versuchsort keine Unterschiede in der überwinterungsfähigkeit bestanden, sind offensichtlich die lokalen Uberwinterungsbedingungen für keine von den beiden ein limitierender oder ein fördernder Faktor. Wegen der Meereshöhe des Versuchsgeländes sind die klimatischen Bedingungen für diesen geographischen Breitengrad nicht typisch, sie ähneln eher der früher angenommenen südlichen Verbreitungsgrenze Afrikanisierter Bienen $\left(32^{\circ} \mathrm{S}\right.$ bis $\left.34^{\circ} \mathrm{S}\right)$. Wenn jedoch irgendwelche von den Bedingungen in Cura Brochero ähnlich denen sind, die das überleben Afrikanisierter Bienen begrenzen, so hätte man zumindest eine erhöhte Mortalität oder Schwächung der Vollvölker, bzw. eine höhere Mortalität oder einen Rückgang der Volksstärke bei den Ablegern erwarten müssen. Also wäre es möglich, daß viel kältere Klimabedingungen nötig sind, um das Überleben Afrikanisierter Bienen zu begrenzen.

Wenn nicht andere Faktoren gefunden werden, die ihre Ausbreitung begrenzen, wie Nahrung, Wasserversorgung oder Nistplätze, so haben wir den Verdacht, daß Afrikanisierte Bienen viel weiter südlich in Argentinien überleben können, als man bisher angenommen hatte. 


\section{REFERENCES CITED}

Collins A.M., Kubasek K.J., 1982. - Field test of honey bee (Hymenoptera, Apidac) colony defensive behavior. Ann. Entomol. Soc. Amer, 75, 383-387.

Collins A.M., Rinderer T.E., Harbo J.R., Bolten A.B., 1982. - Colony defense by Africanized and European honey bees. Science, 218, 72-74.

Darchen R., 1973. - La thermoregulation et l'écologie de quelques espèces d'abeilles sociales d'Afrique (Apidae, Trionini et Apis mellifera var. andansonii). Apidologie, 4 (4), 341-370.

Dietz A., Kreli. R., Eischen F.A., 1985. - Preliminary investigation on the distribution of Africanized honey bees in Argentina. Apidologie, 16 (2), 99-108.

Fletcher D.J.C., 1978. - The African Bee, Apis mellifera adansonii, in Africa. Annt. Rev. Entomol., 23, 151-171.

Fuerza Aerea Argentina, Servicio Meteorologico Nacional. Estadistica Climatologica, 1961-1970. Series $\mathrm{B}, \mathrm{N}^{\circ} 35$, 1 st edition.

HeINRICH B., 1979. - Thermoregulation of Africanized and European honey bees during foraging, attack and hive exits and returns. J. Exp. Bol., 80, 217-229.

Kerr W.E., Leon del Rio S. de, and Barrionuevo M.D., 1982. - The southern limits of the distribution of the Africanized honey bee in South America. Am. Bee J., 122, 196-198.

StorT A.C., 1974. - Genetic study of aggressiveness of two sub-species of Apis mellifera in Brazil. 1. Some tests to measure aggressiveness. J. Apic, Res., 13 (1), 33-38.

TAYLOR O.R., 1977. - Past and possible future spread of Africanized honey bees in the Americas. Bee World, 58, 19-30.

TAYLOR O.R., SPIVAK M., 1984. - Climatic limits of tropical African honey bees in the Americas. Bee World, 65, 38-47.

Woyke J., 1973. - Experiences with Apis mellifera adansonii in Brazil and Poland. Apiacta, 8, 115-116. 